\title{
Proceeding
}

Supplementary Issue: Spring Conferences of Sports Science. Costa Blanca Sports Science Events, 19-20 June 2020. Alicante, Spain.

\section{Change in the "goalkeeper wall" adopted for the training of libero in the volleyball}

\author{
CHRISTIAN LUNATO 14 , ROSARIO CERUSO ${ }^{1}$, RICCARDO IZZO² \\ 1 University of Salerno, Italy \\ 2University of Carlo Bo, Urbino, Italy
}

\begin{abstract}
Research revealed that a soccer goalkeeper and a volleyball libero player have multiple characteristics in common. A fundamental motor gesture in both sports is "dig", a movement that requires a certain level of motor skill. The objectives set at the beginning of this experimentation are the improvement of explosive strength and reactivity. The latter specifically given the variability of the trajectories of the ball. 41 athletes divided between goalkeepers and libero players, aged around 15 years who took part in the respective regional sports championships were taken for observation. The "Reach" and "Vertec" tests were used to obtain the elevation data in $\mathrm{cm}$. In addition, innovative tests were introduced which analyse the technical skills based on the role and play ability. Once the incoming data were obtained, the athletes underwent 2 sessions per week for 2 months to train the characteristics in common between the two roles. At the end of the training period, the athletes were again subjected to the tests mentioned above to find potential changes. At the end of the training program, a clear improvement of the whole sample examined emerged.
\end{abstract}

Keywords: Goalkeeper; Vertec; Reach.

\section{Cite this article as:}

Lunato, C., Ceruso, R., \& Izzo, R. (2020). Change in the "goalkeeper wall" adopted for the training of libero in the volleyball. Journal of Human Sport and Exercise, 15(3proc), S609-S618. doi:https://doi.org/10.14198/jhse.2020.15.Proc3.13

Corresponding author. Department of Human, Philosophical and Education Sciences, University of Salerno, Italy.

E-mail: c.lunato@studenti.unisa.it

Supplementary Issue: Spring Conferences of Sports Science. Costa Blanca Sports Science Events, 19-20 June 2020. Alicante, Spain.

JOURNAL OF HUMAN SPORT \& EXERCISE ISSN 1988-5202

(c) Faculty of Education. University of Alicante

doi:10.14198/jhse.2020.15.Proc3.13 


\section{INTRODUCTION}

A current analysis of scientific research, especially in relation to the speed of its evolution, is very important as an initial moment for the determination of the various phases of the project. As you know, science tends to achieve ever-higher goals, aimed at improving human skills. This can be achieved in any field, but in a specific way, in our case, to achieve the set goals. The figure of the libero was born in the late $90 \mathrm{~s}$, precisely in 1998, when it was introduced by the FIVB. Entering the analysis of the role and of both motor and cognitive skills, we can see a certain similarity with the role of the goalkeeper in football (Manno et al. 2019). Also in other roles it is important to deep the performance (Izzo et al, 2020ab, Izzo et al, 2019abc) as well as in sport performance globally as part of exercise and sport sciences field (Raiola, 2020, Raiola, Altavilla, 2020, Raiola 2019abc, Raiola et al, 2018, Raiola, D'Isanto 2016ab, Raiola 2015abc, Raiola 2014ab, Raiola 2013, Raiola 2011ab, Parisi, Raiola,2016ab).

A fundamental motor gesture in both sports is "diving", a movement that requires a certain level of motor skill (Paolini et al., 2006). At the same time, the ability to anticipate, on a cognitive level, is vital, since it allows the athlete to sense the direction of the ball (Altavilla 2020, Altavilla, Raiola, 2019, Altavilla et al, 2018, Altavilla, Raiola, 2018, Altavilla et al, 2017, Altavilla, Raiola, 2015, Casolo et al., 2007, D'Elia, Raiola, 2019, D'Elia et al, 2019ab, Invernizzi et al, 2020, 2014ab, 2008). In football, there have been various debates and evolutions of the goalkeeper figure, which have better defined what skills a goalkeeper must have to be able to play at high levels. Nowadays the goalkeeper is an active part of the team's schemes (Fattori et al., 2015, Russo et al, 2019ab). In most cases where the action takes place within the defensive area, the goalkeeper is called to touch the ball several times, to give fluidity to the manoeuvres (Cacciatori et al., 2004). In the volleyball field, the figure of the libero is still being studied to seek a further evolution of the role. Many federations have started research projects and refresher courses, placing the figure of the libero as a central topic. There are various hypotheses about it; for example, the design of a new specific coach course for this role, which aims to train coaches with specific and targeted requirements. Given the fundamental importance of this role, he is required to update himself on the results that science proposes, in a precise and rapid way, on all that the latter can confer as regards the tools he needs in carrying out the figure that he covers.

\section{METHODS AND MATERIALS}

\section{Subjects}

The sample examined consists of 41 athletes from the year 2004/2005, in particular 22 goalkeepers and 19 libero ones have been selected.

\section{Experimental design}

The figure of the libero player, as previously mentioned, is a figure born in the 90s and his training methodology differs from that of the entire team. Within volleyball teams, the average height between the players is around $2 \mathrm{~m}$ and, usually, the free distance is even $20 \mathrm{~cm}$ lower than the teammates. This is due to the need to develop certain cognitive and coordinative skills which, starting from certain basic theoretical and practical requirements gradually enrich the player's motor skills, allowing him to perform increasingly complex and optimal performances (Paolini M. et al., 2019). Many technicians have contributed to the continuous evolution of this sports figure through new methodologies and new devices (Urso A. et al., 2020). Going to look in other sports, we realized that some training methodologies could also be used in volleyball (Contadin A. et al., 2019). In this research design, we have chosen a goalkeeper-specific training tool, adapting it to free practice. Through this work and the statistical tool used, it can be demonstrated that the transposition from the goalkeeper to the free one can favour the achievement of the pre-established objectives, which is a 
new training methodology that can be administered in volleyball. This can be demonstrated using the "T-test" and the consequent acceptance of the alternative hypothesis that, in this case, is the significance due to the improvement of the subjects trained with this methodology. The testing of the table took place in collaboration with the amateur clubs "ASD Recale 2002", in the football field and the "ASD Volleyball 2000" for volleyball. The aforementioned companies have grouped the sample number indicated by the researchers in order to carry out the project. The companies were provided with a prototype of the board for use in training during the trial period.

The research project started on 09-09-2019 and ended on 8-12-2019.

The athletes were subjected to initial and final tests to allow researchers to establish initial and final parameters.

In particular, the "Reach" and "Vertec" tests were administered for the data relating to the explosive force.

The team of researchers is made up of various job figures according to their skills:

- Engineers and design experts: creation of a table project.

- Teachers and students in sports sciences: explanation and administration of the table.

- Doctors: supervision during the execution of the tests.

The coach positions himself in front of the table while the goalkeeper or libero player stands between the table and the coach. The instructor will launch, for a series of times defining the planning of the administration of the table, the ball against the wall alternating in striking hemispheres of different material that allow the exercise also on short trajectories. This tool allows training with or without an athletic trainer. On a total of 20 repeated throws or throws for 3 series, the athlete must be able to recover as many balls as possible, intercepting the direction of the ball.

\section{RESULTS}

Table 1. Anthropometric data.

\begin{tabular}{|c|c|c|c|c|c|c|c|c|c|c|c|}
\hline ATHLETE & YEAR & ROLE & $\begin{array}{c}\text { HEIGHT } \\
\text { (cm) }\end{array}$ & $\begin{array}{l}\text { REACH } \\
\text { (1) }(\mathrm{cm})\end{array}$ & $\begin{array}{l}\text { VERTEC } \\
\text { (1) }(\mathrm{cm})\end{array}$ & $\begin{array}{l}\text { C.T.R. } \\
\text { (1) }\end{array}$ & $\begin{array}{c}\text { C.D.G. } \\
\text { (1) }\end{array}$ & $\begin{array}{l}\text { REACH } \\
\text { (2) (cm) }\end{array}$ & $\begin{array}{l}\text { VERTEC } \\
\text { (2) }(\mathrm{cm})\end{array}$ & $\begin{array}{l}\text { C.T.R. } \\
\text { (2) }\end{array}$ & $\begin{array}{l}\text { C.D.G. } \\
\text { (2) }\end{array}$ \\
\hline 1 & 2005 & $\mathrm{~L}$ & 1.72 & 2.25 & 2.84 & 3 & 3 & 2.27 & 2.89 & 4 & 4 \\
\hline 2 & 2004 & P & 1.80 & 2.36 & 3.16 & 3 & 3 & 2.38 & 3.19 & 5 & 4 \\
\hline 3 & 2004 & P & 1.98 & 2.60 & 3.21 & 4 & 4 & 2.61 & 3.25 & 5 & 5 \\
\hline 4 & 2005 & L & 1.78 & 2.36 & 2.92 & 3 & 3 & 2.37 & 3 & 4 & 5 \\
\hline 5 & 2005 & L & 1.78 & 2.37 & 3.01 & 4 & 4 & 2.39 & 3.06 & 4 & 5 \\
\hline 6 & 2004 & P & 1.80 & 2.33 & 3.03 & 3 & 3 & 2.35 & 3.07 & 4 & 5 \\
\hline 7 & 2004 & $P$ & 1.82 & 2.30 & 3.15 & 5 & 4 & 2.32 & 3.21 & 5 & 5 \\
\hline 8 & 2004 & P & 1.93 & 2.46 & 3.10 & 4 & 5 & 2.49 & 3.15 & 5 & 5 \\
\hline 9 & 2005 & P & 1.83 & 2.34 & 2.95 & 5 & 5 & 2.36 & 3.02 & 5 & 5 \\
\hline 10 & 2004 & L & 1.74 & 2.21 & 3.01 & 4 & 4 & 2.24 & 3.01 & 4 & 5 \\
\hline 11 & 2005 & L & 1.73 & 2.22 & 2.89 & 4 & 4 & 2.25 & 2.93 & 5 & 5 \\
\hline 12 & 2004 & P & 1.87 & 2.43 & 2.98 & 5 & 5 & 2.47 & 3.04 & 5 & 5 \\
\hline 13 & 2004 & L & 1.72 & 2.24 & 2.93 & 3 & 5 & 2.26 & 2.99 & 5 & 5 \\
\hline 14 & 2004 & P & 1.85 & 2.40 & 2.92 & 5 & 5 & 2.44 & 2.98 & 5 & 5 \\
\hline 15 & 2004 & L & 1.78 & 2.36 & 3.05 & 4 & 5 & 2.37 & 3.11 & 5 & 5 \\
\hline 16 & 2004 & L & 1.71 & 2.18 & 2.91 & 5 & 4 & 2.21 & 2.97 & 5 & 4 \\
\hline 17 & 2004 & P & 1.84 & 2.44 & 2.98 & 5 & 5 & 2.47 & 3.04 & 5 & 5 \\
\hline 18 & 2004 & L & 1.76 & 2.31 & 2.96 & 4 & 5 & 2.33 & 3.02 & 5 & 5 \\
\hline
\end{tabular}




\begin{tabular}{llllllllllll}
\hline 19 & 2004 & $\mathrm{~L}$ & 1.72 & 2.21 & 2.74 & 5 & 5 & 2.24 & 2.81 & 5 & 5 \\
20 & 2004 & $\mathrm{~L}$ & 1.79 & 2.34 & 3.05 & 4 & 5 & 2.37 & 3.13 & 5 & 5 \\
21 & 2005 & $\mathrm{P}$ & 1.85 & 2.41 & 3.08 & 3 & 3 & 2.46 & 3.15 & 4 & 4 \\
22 & 2005 & $\mathrm{~L}$ & 1.74 & 2.22 & 2.91 & 3 & 3 & 2.29 & 2.96 & 5 & 4 \\
23 & 2004 & $\mathrm{P}$ & 1.81 & 2.36 & 3.06 & 4 & 4 & 2.41 & 3.12 & 5 & 5 \\
24 & 2004 & $\mathrm{P}$ & 1.73 & 2.25 & 2.94 & 3 & 3 & 2.31 & 2.99 & 4 & 5 \\
25 & 2005 & $\mathrm{P}$ & 1.90 & 2.46 & 3.9 & 4 & 4 & 2.5 & 3.14 & 4 & 5 \\
26 & 2005 & $\mathrm{P}$ & 1.86 & 2.43 & 2.97 & 3 & 3 & 2.5 & 3.01 & 4 & 5 \\
27 & 2004 & $\mathrm{~L}$ & 1.70 & 2.19 & 2.92 & 5 & 4 & 2.24 & 2.97 & 5 & 5 \\
28 & 2005 & $\mathrm{P}$ & 1.82 & 2.3 & 3.13 & 4 & 5 & 2.36 & 3.2 & 5 & 5 \\
29 & 2004 & $\mathrm{~L}$ & 1.78 & 2.29 & 3.1 & 5 & 5 & 2.35 & 3.6 & 5 & 5 \\
30 & 2005 & $\mathrm{~L}$ & 1.77 & 2.28 & 2.93 & 4 & 4 & 2.34 & 2.97 & 4 & 5 \\
31 & 2005 & $\mathrm{P}$ & 1.83 & 2.33 & 3.03 & 4 & 4 & 2.4 & 3.1 & 5 & 5 \\
32 & 2005 & $\mathrm{P}$ & 1.86 & 2.38 & 3.01 & 5 & 5 & 2.44 & 3.19 & 5 & 5 \\
33 & 2004 & $\mathrm{P}$ & 1.87 & 2.4 & 2.91 & 3 & 5 & 2.48 & 2.96 & 5 & 5 \\
34 & 2005 & $\mathrm{~L}$ & 1.80 & 2.31 & 2.95 & 5 & 5 & 2.37 & 3 & 5 & 5 \\
35 & 2004 & $\mathrm{P}$ & 1.85 & 2.38 & 2.94 & 4 & 5 & 2.44 & 2.99 & 5 & 5 \\
36 & 2005 & $\mathrm{~L}$ & 1.77 & 2.27 & 2.92 & 5 & 4 & 2.33 & 2.98 & 5 & 4 \\
37 & 2004 & $\mathrm{P}$ & 1.84 & 2.34 & 2.95 & 5 & 5 & 2.41 & 3.1 & 5 & 5 \\
38 & 2005 & $\mathrm{P}$ & 1.85 & 2.36 & 3.04 & 4 & 5 & 2.41 & 3.1 & 5 & 5 \\
39 & 2004 & $\mathrm{~L}$ & 1.77 & 2.28 & 2.93 & 5 & 5 & 2.35 & 2.99 & 5 & 5 \\
40 & 2005 & $\mathrm{~L}$ & 1.68 & 2.18 & 2.9 & 4 & 5 & 2.24 & 3.5 & 5 & 5 \\
41 & 2005 & $\mathrm{P}$ & 1.83 & 2.33 & 2.98 & 4 & 4 & 2.39 & 3.3 & 5 & 4 \\
\hline
\end{tabular}

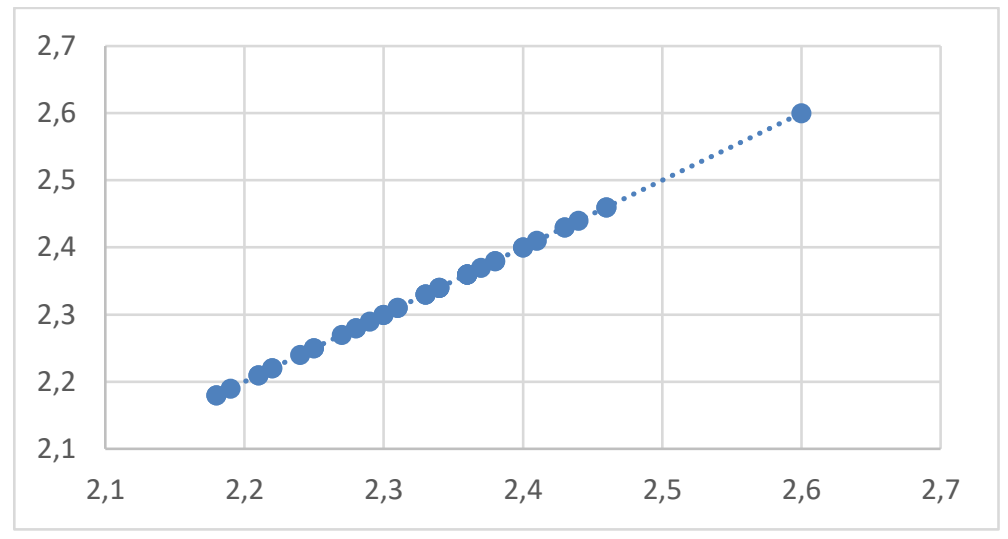

Figure 1. Scatter chart Reach test.

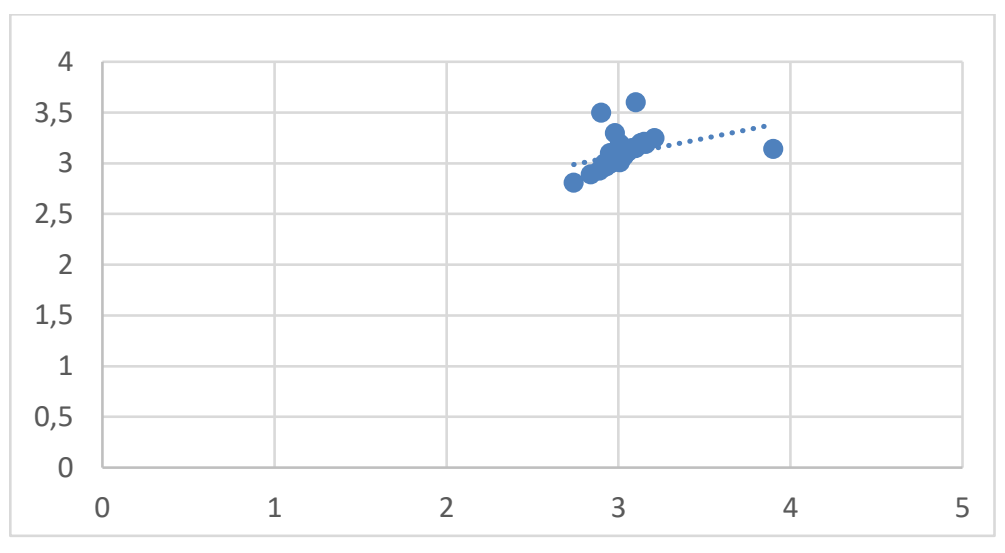

Figure 2: Scatter chart Vertec test. 
Table 4. T-test play ability.

\begin{tabular}{lll}
\hline & Variable 1 & Variable 2 \\
\hline Media & 4.3 & 4.85 \\
Variance & 0.625641026 & 0.130769231 \\
Observation & 40 & 40 \\
Total variance & 0.378205128 & \\
Difference hypothesized for the media & 0 & \\
DoF & 78 & \\
Stat $t$ & -3.999576249 & \\
$\mathrm{p}(\mathrm{T}<=\mathrm{t})$ one tail & $7.16079 \mathrm{E}-05$ & \\
$\mathrm{t}$ critical one tail & 1.664624645 & \\
$\mathrm{p}(\mathrm{T}<=\mathrm{t})$ two tail & 0.000143216 & \\
$\mathrm{t}$ critical two tail & 1.990847069 & \\
\hline
\end{tabular}

Table 5. T-test technical skills by role.

\begin{tabular}{lll}
\hline & Variable 1 & Variable 2 \\
\hline Media & 4.097560976 & 4.756097561 \\
Variance & 0.590243902 & 0.18902439 \\
Observation & 41 & 41 \\
Total variance & 0.389634146 & \\
Difference hypothesized for the media & 0 & \\
DoF & 80 & \\
Stat $t$ & -4.776704032 & \\
$\mathrm{p}(\mathrm{T}<=\mathrm{t})$ one tail & $3.97178 \mathrm{E}-06$ & \\
$\mathrm{t}$ critical one tail & 1.664124579 & \\
$\mathrm{p}(\mathrm{T}<=\mathrm{t})$ two tail & $7.94356 \mathrm{E}-06$ & \\
$\mathrm{t}$ critical two tail & 1.990063421 & \\
\hline
\end{tabular}

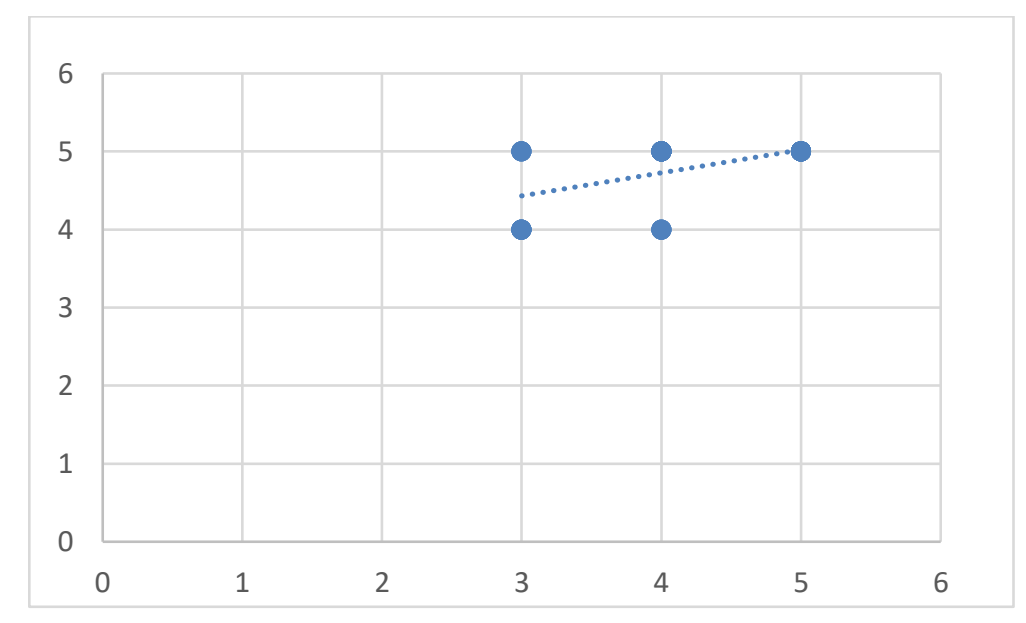

Figure 3: Scatter chart technical skills by role. 


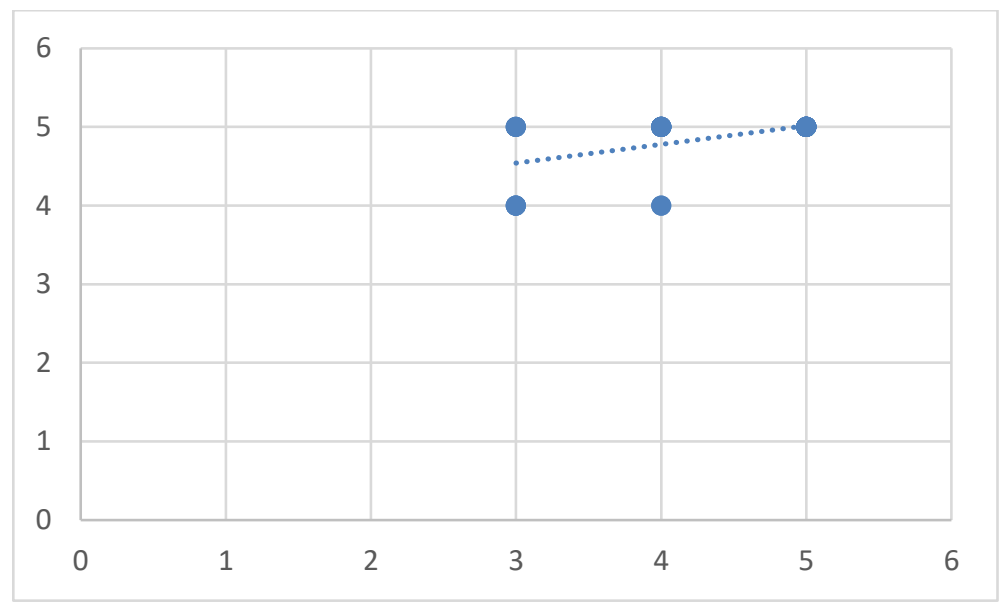

Figure 4. Scatter chart play ability.

Table 4. T-test play ability.

\begin{tabular}{lll}
\hline & Variable 1 & Variable 2 \\
\hline Media & 4.3 & 4.85 \\
Variance & 0.625641026 & 0.130769231 \\
Observation & 40 & 40 \\
Total variance & 0.378205128 & \\
Difference hypothesized for the media & 0 & \\
DoF & 78 & \\
Stat $t$ & -3.999576249 & \\
$\mathrm{p}(\mathrm{T}<=\mathrm{t})$ one tail & $7.16079 \mathrm{E}-05$ & \\
$\mathrm{t}$ critical one tail & 1.664624645 & \\
$\mathrm{p}(\mathrm{T}<=\mathrm{t})$ two tail & 0.000143216 & \\
$\mathrm{t}$ critical two tail & 1.990847069 & \\
\hline
\end{tabular}

Table 5. T-test technical skills by role.

\begin{tabular}{lll}
\hline & Variable 1 & Variable 2 \\
\hline Media & 4.097560976 & 4.756097561 \\
Variance & 0.590243902 & 0.18902439 \\
Observation & 41 & 41 \\
Total variance & 0.389634146 & \\
Difference hypothesized for the media & 0 & \\
DoF & 80 & \\
Stat $t$ & -4.776704032 & \\
$p(T<=t)$ one tail & $3.97178 \mathrm{E}-06$ & \\
$\mathrm{t}$ critical one tail & 1.664124579 & \\
$\mathrm{p}(\mathrm{T}<=\mathrm{t})$ two tail & $7.94356 \mathrm{E}-06$ & \\
$\mathrm{t}$ critical two tail & 1.990063421 & \\
\hline
\end{tabular}




\section{DISCUSSION}

In Table 1, the incoming and outgoing data have been reported, respectively marked by the numbers 1 and 2, obtained with the following tests:

- Reach test: it is the height value reached with the arm stretched up, keeping the feet on the ground.

- Vertec test: it is the height value reached after jumping simulating the technical gesture of the dunk.

- C.T.R: Technical skills based on the role; score attributed by an evaluation of the fundamentals acquired by the athlete based on the role during specific training following the pre-established guidelines on the attribution of the score, using the variation of the "goalkeeper wall" by establishing the following parameters:

- 2: player with bad technical skills based on the role. From 0 to 5 balls recovered.

- 3: player with normal technical skills based on the role. From 5 to 10 balls recovered.

- 4: player with good technical skills based on the role. From 10 to 15 balls recovered.

- 5: player with excellent technical skills based on the role. From 15 to 20 balls recovered.

- C.D.G: Game Skill: score attributed with a game evaluation of the player in certain game schemes following the guidelines on the attribution of the score:

- 2: player with poor game skills.

- 3: player with normal game skills

- 4: player with good game skills

- 5: player with excellent game skills

In these scatter plots (Figures 2; 3) the values obtained from the Reach and Vertec tests have been reported both inbound and outbound. Looking at the line of linear regression, there is an improvement in the output results compared to the initial results of almost all athletes. This type of test-t (Tables 2,3), with dependent samples assuming various variances, is used to evaluate improvements or worsening of the same group, placing a null hypothesis and an alternative hypothesis.

Null hypothesis: possible improvements but not due to the training methodology. They can be attributed either to chance or to a variable that has not been taken into consideration.

Alternative hypothesis: possible improvements due to the training methodology used.

In order that the alternative hypothesis to be accepted, the "two-tailed $p(T<=t)$ " is less than .05 , obtaining an error margin of $5 \%$. If the value obtained falls within the $5 \%$ error margin, the alternative hypothesis is accepted. Therefore, the value of the "two-tailed $p(T<=t)$ " shown in the previous tables is within the predetermined margin of error; for this reason, the alternative hypothesis is accepted and the training methodology performed is effective. The data obtained from the tests to evaluate the technical skills based on the role and the game skills, were also analysed through scatter charts and the T-test. Also, in their respective scatter plots (Figures 4,5 ) we note the upward trend of the line of the linear regression. This shows an improvement in these skills.

Analysing the T-test fees (Tables 4,5), it shows that the value of the "p ( $T<=t)$ two-tailed" is less than .05 therefore it falls within the predetermined margin of error. 


\section{CONCLUSION}

The project, structured in two parts through the analysis of the goalkeeper's role in football and the role of the libero player in volleyball, reaches particularly interesting and concrete conclusions in the second part. Inside it, conducted on an entirely experimental basis, the data collected from the tests carried out are reported.

The work provides constructive alternatives and valid tools for training, especially in view of the further future developments that lie ahead. The analysis of the responses to the stimulus administered was very useful. This is above all because, by making contractions appropriate to the situations, it was possible to reflect on the fact that the reaction times depend on the greatest possible number of stimulus-response alternatives. It is precisely the variation of the stimulus that provokes increasingly effective reactions, also considering that the effectiveness of the performance is closely related to the speed to take lightning, adequate and correct decisions.

From the data obtained, the researchers found an improvement in coordination skills; in particular some athletes have developed explosive strength in greater ways by improving the final test result by several centimetres.

Having obtained feedback in both sports, this board can be defined as a "multipurpose or bifunctional board" given its effectiveness in both sports.

\section{REFERENCES}

Altavilla, G. (2019) Monitoring training to adequate the teaching method in training: an interpretative concepts Journal of Physical Education and Sport Vol.19 (Supplement issue 5), Art 258, pp. 17631766.

Altavilla, G., D'Elia, F., Raiola, G. (2018) A breif review of the effects of physical activity in subjects with cardiovascular disease: An interpretative key, Sport Mont, 16 (3), pp. 103-106. https://doi.org/10.26773/smj.181018

Altavilla, G., D'Isanto, T., Di Tore, A.P., Raiola, G. (2018) Free throw and outcomes: Pilot study on intensive training versus extensive one, Journal of Human Sport and Exercise, 13 (3), pp. 494-503. https://doi.org/10.14198//hse.2018.133.02

Altavilla, G., Gaetano, R. (2018) Physiological effects of warm-up and problems related to team sports, Sport Science, 11, pp. 83-88.

Altavilla, G., Raiola, G. (2015) Sports game tactic in basketball [Sport Science, 8 (1), pp. 43-46.

Altavilla, G., Raiola, G. (2019) A brief review on physiological commitment in basketball: An interpretative key, Journal of Human Sport and Exercise, 14, pp. S59-S65. https://doi.org/10.14198//hse.2019.14.proc1.07

Altavilla, G., Riela, L., Di Tore, A.P., Raiola, G. (2017) The physical effort required from professional football players in different playing positions. Journal of Physical Education and Sport, 17 (3), art. no. 200, pp. 2007-2012.

Cacciatori M., II portiere moderno: preparazione fisica, tecnica e tattica con programma generale di lavoro, Edizioni Librati, Acquaviva Picena, 2004.

Casolo F., Lineamenti di teoria e metodologia del movimento umano, V\&P, Roma, 2007.

Contadin A. Sesia M., Preparazione fisica pallavolo nel settore giovanile Under 16, BZ Hi-tech, Rovigo, 2019. 
D'Elia, F., Cassese, F.P., D'isanto, T. (2019a) Augmented, virtual and robotics reality for distance learning and internship in telematics Sport and Exercise Science degrees in Italy Journal of Human Sport and Exercise, 14, pp. S792-S796. https://doi.org/10.14198/hhse.2019.14.proc4.41

D'Elia, F., D'Isanto, T., \& Altavilla, G. (2019). Training and performance in the transition period. Journal of Human Sport and Exercise, 14(2proc), S258-S262. https://doi.org/10.14198/ihse.2019.14.Proc2.15

D'Elia, F., Raiola, G. (2019) Sport and Exercise Sciences Degrees in Italy: Comparison Between Online and Traditional Teaching Models, Communications in Computer and Information Science, 1091, pp. 209-216. https://doi.org/10.1007/978-3-030-31284-8_16

Fattori L., Addestramento e formazione del portiere, Calzetti \& Mariucci, Perugia, 2015.

Fattori L, II portiere che gioca. I cambiamenti del ruolo in funzione dell'evoluzione del calcio, Calzetti e Mariucci Editori, Torgiano, 2019.

Invernizzi, P.L., Limonta, E., Bosio, A., Scurati, R., Veicsteinas, A., Esposito, F. (2014a) Effects of a 25$\mathrm{km}$ trial on psychological, physiological and stroke characteristics of short- And mid-distance swimmers Journal of Sports Medicine and Physical Fitness, 54 (1), pp. 53-62.

Invernizzi, P.L., Longo, S., Scurati, R., Maggioni, M.A., Michielon, G., Bosio, A. (2014b) Interpretation and perception of slow, moderate, and fast swimming paces in distance and sprint swimmers Perceptual and Motor Skills, 118 (3), pp. 833-849. https://doi.org/10.2466/27.29.pms.118k23w0

Invernizzi, P.L., Longo, S., Scurati, R. (2008) Analysis of heart rate and lactate concentrations during coordinative tasks: Pilot study in karate kata world champions Sport Sciences for Health, 3 (1-2), pp. 41-46. https://doi.org/10.1007/s11332-008-0053-7

Invernizzi, P.L., Signorini, G., Bosio, A., Raiola, G., Scurati, R. (2020) Validity and reliability of selfperception-based submaximal fitness tests in young adult females: An educational perspective Sustainability, 12 (6). https://doi.org/10.3390/su12062265

Izzo, R., D'isanto, T., Raiola, G., Cejudo, A., Ponsano, N., Varde'i, C.H. (2020b) The role of fatigue in football matches, performance model analysis and evaluation during quarters using live global positioning system technology at 50hz, Sport Science, 13 (1), pp. 30-35.

Izzo, R., Giovannelli, M., Raiola, G. (2019a) Training load in elite goalkeepers with k-track for monitoring performance, Journal of Physical Education and Sport, 19, art. no. 280, pp. 1890-1896.

Izzo, R., Giovannelli, M., D'isanto, T. (2019b) The injury prevention program WTA functional primitive movement in professional football players: A case study Journal of Physical Education and Sport, 19 , art. no. 279 , pp. $1885-1889$.

Izzo, R., Giovannelli, M., D'isanto, T. The injury prevention program WTA functional primitive movement in professional football players: A case study (2019c) Journal of Physical Education and Sport, 19, art. no. 279 , pp. 1885-1889.

Manno R. Le capacità coordinative, Scuola dello sport - Rivista di cultura sportiva, Roma, 1984.

Paolini M., II nuovo sistema pallavolo. Tecnica, tattica e didattica con esercitazioni pratiche, Calzetti e Mariucci editori, Perugia, 2006.

Paolini M. Giannini R. Quintini A., II libero nella pallavolo moderna nuove competenze e qualifiche, Calzetti Mariucci editori, Torgiano, 2019.

Parisi, F., Raiola, G. (2014a) The serve in under 12-13 Italian volleyball team, Journal of Human Sport and Exercise, 9, pp. S588-S591. https://doi.org/10.14198//hse.2014.9.proc1.51

Parisi, F., Raiola, G. (2014b) Video analysis in youth volleyball team, Journal of Human Sport and Exercise, 9, pp. S584-S587. https://doi.org/10.14198/ihse.2014.9.proc1.50

Raiola, G., \& Altavilla, G. (2020). Testing motor skills, general and special coordinative, in young soccer. Journal of Human Sport and Exercise, 15(2proc), S206-S212. https://doi.org/10.14198//hse.2020.15.proc2.11 
Raiola, G. (2020) The Movement and Sport Science in Italy towards the European Research Council, Physical Culture and Sport, Studies and Research, 86 (1), pp. 37-48. https://doi.org/10.2478/pcssr2020-0011

Raiola, G. (2019a) Complex study for an epistemology of exercise and sport sciences: A)keyconceptsofboth ERC subpanels and CUN keywords; b) physical training and sport methodology sciences academic disciplines in pedagogy recruitment sector and biomedical one: $\mathrm{A}$ correlationships study. Journal of Physical Education and Sport, 19, art. no. 255, pp. 1748-1754.

Raiola, G. (2019b) Comparison of exercise and sport sciences epistemology between european research council structure panel and Italian academic system. Sport Science, 12, pp. 112-120.

Raiola, G. (2019). Survey on exercise and sport sciences in Italy. Journal of Human Sport and Exercise, 14(4proc), S1163-S1168. https://doi.org/10.14198/jhse.2019.14.Proc4.81

Raiola, G. (2017) Motor learning and teaching method, Journal of Physical Education and Sport, 17, art. no. 236, pp. 2239-2243.

Raiola, G., D'elia, F., Altavilla, G. (2018) Physical activity and sports sciences between European Research Council and academic disciplines in Italy, Journal of Human Sport and Exercise, 13, pp. S283-S295. https://doi.org/10.14198/ihse.2018.13.proc2.13

Raiola, G., D'isanto, T. (2016a) Descriptive shot analysis in basketball, Journal of Human Sport and Exercise, 11 (Proc1), pp. S259-S266. https://doi.org/10.14198/jhse.2016.11.proc1.18

Raiola, G., D'isanto, T. (2016b) Assessment of periodization training in soccer, Journal of Human Sport and Exercise, 11 (Proc1), pp. S267-S278. https://doi.org/10.14198/jhse.2016.11.proc1.19

Raiola, G. (2015a) Inclusion in sport dance and self perception Sport Science, 8, pp. 99-102.

Raiola, G. (2015b) Sport skills and mental health, Journal of Human Sport and Exercise, 10 (Specialissue), pp. S369-S376. http://dx.doi.org/10.14198/jhse.2015.10.Proc1.27

Raiola, G. (2015c) Basketball feint and non-verbal communication: Empirical framework, Journal of Human Sport and Exercise, 10 (Specialissue1), pp. 360-368. https://doi.org/10.14198/ihse.2015.10.proc1.26

Raiola, G. (2014a) Teaching method in young female team of volleyball, Journal of Physical Education and Sport, 14 (1), pp. 74-78.

Raiola, G. (2014b) Motor control and learning skills according to cognitive and ecological dynamic approach in a vision on behaviorism, cognitive, Gestalt and phenomenology theories, Mediterranean Journal of Social Sciences, 5 (15), pp. 504-506. https://doi.org/10.5901/mjss.2014.v5n15p504

Raiola, G. (2013) Body knowledge and motor skills, Knowledge Cultures, 1 (6), pp. 64-72.

Raiola, G. (2011a) A study on Italian primary school rules: Neurophysiological and didactics aspects on physical education and sport, Journal of Physical Education and Sport, 11 (2), pp. 43-48.

Raiola, G. (2011b) Study between neurophysiological aspects and regulation documents on preschool in Italy, Journal of Physical Education and Sport, 11 (1), pp. 42-47.

Russo, G., Nigro, F., Raiola, G., Ceciliani, A. (2019a) The role of the extra physical activity on memory storage and psychosocial features Journal of Human Sport and Exercise, 14 (Proc4), pp. S948S956. https://doi.org/10.14198/jhse.2019.14.proc4.57

Russo, G., Nigro, F., Raiola, G., Ceciliani, A. (2019b) Self-esteem in physically active middle school students Journal of Physical Education and Sport, 19, art. no. 295, pp. 1984-1988.

Urso A., allenare la forza nei giovani, Calzetti e Mariucci editori, Perugia, 2020.

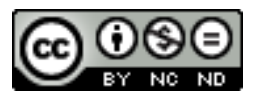

This work is licensed under a Attribution-NonCommercial-NoDerivatives 4.0 International (CC BY-NC-ND 4.0). 